\title{
Identification of Essential Elements in Maintaining Efficient Boiler System of a Coal Fired Thermal Power Plant
}

\author{
T. Sivageerthi, S. Bathrinath, S. Sarvanasankar
}

\begin{abstract}
Electric power is most inevitable one among the other sources of energy. It plays prime role in all developed and developing countries. More than eighty percentage of the electric power are generated from coal fired thermal power plants, in it the thermal energy available in coal is released by firing inside the boiler and transferred to water to generate the super-heated steam. All the released thermal energy inside the boiler cannot be transferred in to the water. Some percentage of heat energy gets lost to the environment without any beneficial uses. If the boiler maintains and operates in correct way, the losses can be minimized and efficiency can be improved. There are so many enablers to efficiently manage the boiler in both maintenance and operation point of view. By using ISM (Interpretive structural modeling) method, identified the relationships of enabler and they are weak in the interpretation of enabler links. To control this, TISM (Total interpretive structural modeling) is used in this paper and it is a modeling with qualitative technique. For the enablers of boiler system, this method is very useful for creating the performance model in structural form. In addition to this, the interaction between all elements of enablers can be easily identified by developed structural model of this methodology. If most important enablers which influence the efficiency of the boiler is concentrates is very easy to maintain designed efficiency of boiler. This work is narrated in this article.
\end{abstract}

Keywords: Boiler system, DM water, TISM.

\section{INTRODUCTION}

The boiler is most important major component in coal fired thermal power station. Any impacts such as the reduction in boiler efficiency will affect the overall thermal power plant efficiency. Excellence in boiler means operating the boiler with minimum loses. By burning the coal, percentage of the total energy potentially available and the percentage of useful heat available by the coal boiler efficiency. There are many heat losses in the boiler, it is due to loss of heat through dry flue gas, due to radiation, moisture in fuel, blow down and burning of hydrogen etc. These loses are majorly classified as operational losses and maintenance losses. Operational losses are heat losses due to blow down steam, due to excess air operation, fuel unburned, periodic

Revised Manuscript Received on December 30, 2019.

* Correspondence Author

T.Sivageerthi, Department of mechancical engineering, Kalasalingam Academy of research and education, Krishnankoil-626126, India. Email: sivageerthi@gmail.com

S.Bathrinath*, Department of mechancical engineering, Kalasalingam Academy of research and education, Krishnankoil-626126, India. Email: bathri@gmail.com

S.Saravanasankar,Department of mechancical engineering, Kalasalingam Academy of research and education, Krishnankoil-626126, India. Email: ssaravanasankar@klu.ac.in soot blowing, due to moist coal etc. The losses due to poor maintenance are poor insulation, furnace air ingression, losses in air pre heater etc. By consulting with the boiler experts the most influencing enablers contributing to the boiler efficiency are listed. Apart from the efficiency drop in thermal power plants, the environmental problem associated with the thermal power plants need to be addressed. In the fast developing world, almost it is impossible to live a day without electricity but the adverse impact left by the thermal power plant on environment is also needed to be addressed. The waste generated form the thermal power plant includes fly ash, release of toxic materials like sulfates and flue gases. Mitigating or eliminating the wastes generation in thermal power plant has been a global scenario. China, by its rapid industrialization policy developed many industries and to deliver the necessary power, constructed many thermal power plants. But, as a result of enormous wastes generated from the thermal power plant, most the environment and population were affected badly.

According to the air-quality test carried by Hao et al. [1] it was identified that most of the urban areas are heavily polluted by the thermal power plant wastes and suggested some control measures like changing the fuel, using dust controller and denitration of flue gases. Study by Guttikunda \& Jawahar [2] in Indian environment also pointed out similar adverse environmental impact by thermal power plant and advised to adhere with stringent environmental protocol for mitigating adverse environmental impacts. In thermal power plant, the available heat energy in coal is released by firing inside the furnace. Furnace situated inside the boiler, in the demineralized water, heat energy released is transferred through the water wall tube portion. Already the water feed to the boiler is preheated by the regenerative heaters. Steam produced in the water wall tubes are collected in top portion of the drum. To reduce the calcium and magnesium concentration of DM water in the boiler drum phosphate is dozing in to the drum; it forms the concentrated minerals in DM water in to the mud like substance and can be remove by continuous blow down (CBD) of steam from the drum. The saturated stem collected in the top of the boiler is heated further in various super heaters situated in flue gas path. The final super-heated steam coming out from boilers fed in to the steam turbine; here converting the heat energy available in steam into mechanical work. Electric generator is coupled to the steam turbine thus generate electric power. The simple thermal power plant layout is given in Figure 1.

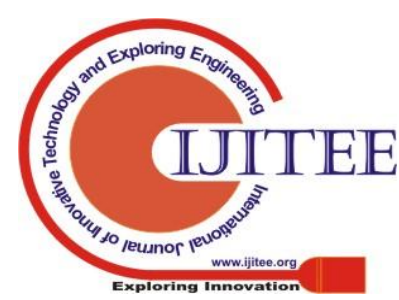




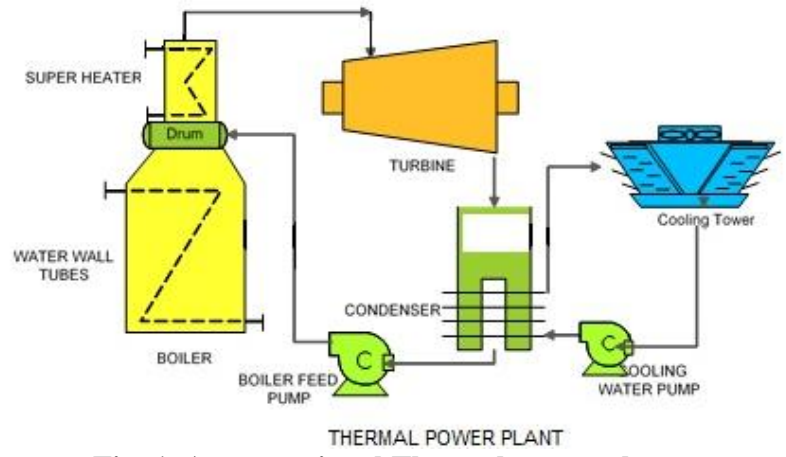

Fig. 1. A conventional Thermal power plant

\section{RELEVANT LITERATURE}

Around the world, the necessity for improving the efficiency of thermal power plant has been on vertical horizon. As coal has been the sole raw material utilized in thermal power plant over years, it leads to complete depletion and shortage. The demand for power supply has been mounting as a result of rapid industrialization and urbanization. With the view of reducing the over dependence on coal fired thermal power plant, Mahkamov et al. [3] developed a thermal power plant with small solar for the purpose of domestic and industrial. The developed solar based thermal power plant effectively served the desired purpose. Das Adhikary et al. [4] studied the critical factors associated with the efficiency of thermal power plant like economizer and identified erosion at economizer leads to efficiency drop in thermal power plant. The major reason for efficiency drop in thermal power plant is due to the risk negligence. Often we came across the news like some XYZ power plant has been shut down due to breakdown. Hence an established risk analysis should be conducted in power plant before operating the plants. Eti et al. [5] analyzed the different factors that need to be accounted for improving the reliability and risk mitigation of thermal power plant. With the consideration of improving efficiency, most the developing nations are allowing private sectors into energy sectors as private sectors harness the optimum skills and technologies. Gupta et al. [6] studied about the major factors influencing the success of Public-Private Partnership (PPP) in carrying out Built-Operate-Transfer (BOT) basis power plant in India and cash-inflow as the major factor influencing the success of PPP.

Liu et al. [7] identified the consequences of Greenhouse gases (GHG) released from the thermal power plant and its adverse influence on the environment. Most of the developed cities in China are facing severe air pollution problem as a result GHGs released from thermal power plant. Goerndt et al. [8] identified some factors that could compensate the over dependence on coal material. As a result of PPP, a private sector came up with an idea of using biomass waste with the coal-fired thermal plant. On validating the success rate, a gradual decrease in the emission of GHG was witnessed. Regulagadda et al. [9] estimated the efficiency drop in thermal power plant due to boiler and turbine losses using a mathematical model.

\section{METHODOLOGY}

Sushil [10] suggested the method of TISM is made from the ISM method and it is initiated by [11]. Recently, many researchers used TISM method for analysing the problem [12-14]. The phase by phase TISM procedure was discussed in detail below:

Phase 1: In the first phase, to identify the elements from literature survey as well as opinions from industrial experts.

Phase 2: Based on the comments from industrial experts, to make the framework regarding the elements and it is vital to describe the contextual relationship among factors.

Phase 3: For each set of factors, to check there is a specific interrelation and also to clarify from experts.

Phase 4: Construct the pair wise comparison matrix for each factor and put the 'Yes' or 'No' relation.

Phase 5: Converting pairwise comparison matrix into initial relationship matrix by applying 1 allocated for 'Yes' and 0 allocated for 'No'.

Phase 6: To attain the final reachability matrix from phase 5. Based on the antecedents and reachability sets, to partition the final reachability into various levels and it is termed as level partition.

Phase 7: Based on the levels, arranged the elements in graphical form and also as per the relations to connect the links.

Phase 8: Construct the interaction matrix by translating the final diagraph with the entry of 1 .

Phase 9: Model of TISM is drawn by which, if all the links are interpreted and they are written in between the related links. This model is finally made any slight modification and it is tested by conceptual discrepancies.

Step by step analysis: All the elements which contribute to attain the maximum efficiency of boiler are listed after consulting with boiler experts. The elements are tabulated in Table 1.

The flow diagram of the paper is presented in Figure 1.

Table- I. Identified elements

\begin{tabular}{|c|c|c|}
\hline $\begin{array}{c}\text { Sl.No } \\
\cdot\end{array}$ & Code & Elements \\
\hline 1 & E1 & Periodical soot blowing \\
\hline 2 & E2 & proper water treatment and blow down control \\
\hline 3 & E3 & Draft control \\
\hline 4 & E4 & Excess air control \\
\hline 5 & E5 & Percentage loading of boiler \\
\hline 6 & E6 & Steam generating pressure and temperature \\
\hline 7 & E7 & Foiler insulation process \\
\hline 8 & E8 & Flue gas temperature \\
\hline 9 & E9 & Ambient air temperature \\
\hline 10 & E10
\end{tabular}

\section{A. Developing of initial reachability matrix}

There are totally ten elements are identified which essential for maintain the boiler efficiency to the designed level. These elements are arranged in row wise and column wise as shown in the Table 2. The' i1 ' is favorable or support to the ' $\mathrm{j} 1$ ' the intersecting place is marked as ' 1 ', if the is no impact or no relation is marked with ' 0 '. Using the same logic all the elements of initial reachability matrix are filled. Here the important elements which contributing in maintain the boiler efficiency to its designed level. The relationship between the each elements in the matrix with other elements are analysed with the boiler experts. Based on the expert advice the relationship is filled.

Table- II. Initial reachability matrix

\begin{tabular}{|l|l|l|l|l|l|l|l|l|l|l|}
\hline Factors & F1 & F2 & F3 & F4 & F5 & F6 & F7 & F8 & F9 & F10 \\
\hline F1 & 1 & 0 & 0 & 0 & 1 & 1 & 0 & 0 & 1 & 0 \\
\hline F2 & 0 & 1 & 0 & 0 & 1 & 1 & 0 & 0 & 1 & 0 \\
\hline F3 & 0 & 0 & 1 & 1 & 1 & 1 & 0 & 1 & 1 & 1 \\
\hline F4 & 0 & 0 & 1 & 1 & 0 & 1 & 1 & 1 & 1 & 0 \\
\hline F5 & 0 & 0 & 1 & 1 & 1 & 1 & 0 & 1 & 1 & 1 \\
\hline F6 & 0 & 0 & 0 & 0 & 1 & 1 & 0 & 0 & 1 & 0 \\
\hline F7 & 0 & 0 & 0 & 0 & 1 & 1 & 1 & 0 & 1 & 0 \\
\hline F8 & 0 & 0 & 0 & 0 & 1 & 1 & 0 & 0 & 1 & 0 \\
\hline F9 & 1 & 0 & 1 & 1 & 1 & 1 & 0 & 1 & 1 & 0 \\
\hline F10 & 0 & 0 & 1 & 1 & 1 & 1 & 1 & 1 & 1 & 1 \\
\hline
\end{tabular}


Table- III. Final reachability matrix

\begin{tabular}{|l|l|l|l|l|l|l|l|l|l|l|}
\hline Factors & F1 & F2 & F3 & F4 & F5 & F6 & F7 & F8 & F9 & F10 \\
\hline F1 & 1 & 0 & $1^{*}$ & $1^{*}$ & 1 & 1 & 0 & $1^{*}$ & 1 & $1^{*}$ \\
\hline F2 & $1^{*}$ & 1 & $1^{*}$ & $1^{*}$ & 1 & 1 & 0 & $1^{*}$ & 1 & $1^{*}$ \\
\hline F3 & $1^{*}$ & 0 & 1 & 1 & 1 & 1 & $1^{*}$ & 1 & 1 & 1 \\
\hline F4 & $1^{*}$ & 0 & 1 & 1 & $1^{*}$ & 1 & 1 & 1 & 1 & 0 \\
\hline F5 & $1^{*}$ & 0 & 1 & 1 & 1 & 1 & $1^{*}$ & 1 & 1 & 1 \\
\hline F6 & $1^{*}$ & 0 & $1^{*}$ & $1^{*}$ & 1 & 1 & 0 & $1^{*}$ & 1 & $1^{*}$ \\
\hline F7 & $1^{*}$ & 0 & $1^{*}$ & $1^{*}$ & 1 & 1 & 1 & $1^{*}$ & 1 & $1^{*}$ \\
\hline F8 & 0 & 0 & $1^{*}$ & $1^{*}$ & 1 & 1 & 0 & 0 & $1^{*}$ & $1^{*}$ \\
\hline F9 & 1 & 0 & 1 & 1 & 1 & 1 & $1^{*}$ & 1 & 1 & 0 \\
\hline F10 & $1^{*}$ & 0 & 1 & 1 & 1 & 1 & 1 & 1 & 1 & 1 \\
\hline
\end{tabular}

\section{RESULT AND DISCUSSIONS}

The final reachability matrix describes relation among the various elements in the matrix. One can clearly understand the essential elements of boilers system and their relations, such as supporting or no relation can be easily identified. The level matrix pin points the rank of each element among ten elements, priority will be given in the works pertaining first rank elements. In our case the elements E3, E4, E5 and E9 are first rank elements. Draft control (E3), Excess air control (E4), percentage loading of boiler (E5) and flue gas temperature (E9) these four elements are maintained by the boiler operation. Continuous monitoring and made the correction, if there is any deviation occurred from its designed value. By taking more attention on these four top elements, the boiler efficiency will be maintained to the designed level. The second rank elements are Fuel quality (F8) and ambient air temperature (F10). Good quality fuel will give more heat in less fuel, due to the reduced quantity of fuel the charges on fuel handling is reduced. Flue gas emission is reduced and controlled easily. The ambient air temperature is based on the geographical location. Hot and cold weather has its own advantages and disadvantages. Cold climates help in steam condensation process but it has more heat dissipation to atmosphere. Third rank element is Periodical soot blowing (F1).

It cleans the boiler internal heat transfer surface by using steam. Water wall soot blower, long retractable soot blowers (LRSB) are to remove the ash deposits inside the boiler and affect heat transfer drastically. The forth rank elements are 'proper water treatment and blow down control', (F2) and Boiler insulation process (F7). Blow down of sediments from the boiler drum is essential one to keep-up the DM water concentration in the continuous circulating water in system. But there is a chance to loss more heat from the system due to high blow down. The insulation is the fore most important since all the process is isentropic process hence, the heat transfer to the atmosphere is avoided. The lacking in insulation process reduces the boiler efficiency.

\section{CONCLUSION}

Based on the boiler expert advice the driving elements which are affecting the boiler performance in large scale are identified and tabulated. The relation between the elements and the degree of relation especially the level ranking are ascertained by this analysis. This analysis explicit the level of importance of various elements. From the ranking, The Ist level elements are to be given much importance; the boiler efficiency will be maintained to the designed level. Other elements may be observed based on their level of ranking. This is easy to all boiler engineers to giving proper importance and monitoring continuously thus increase boiler efficiency and reduces cost of generation.

\section{APPENDIX}

Table- IV: Final reachability matrix

\begin{tabular}{|l|l|l|l|l|l|l|l|l|l|l|}
\hline Factors & F1 & F2 & F3 & F4 & F5 & F6 & F7 & F8 & F9 & F10 \\
\hline F1 & 1 & 0 & $1^{*}$ & $1^{*}$ & 1 & 1 & 0 & $1^{*}$ & 1 & $1^{*}$ \\
\hline F2 & $1^{*}$ & 1 & $1^{*}$ & $1^{*}$ & 1 & 1 & 0 & $1^{*}$ & 1 & $1^{*}$ \\
\hline F3 & $1^{*}$ & 0 & 1 & 1 & 1 & 1 & $1^{*}$ & 1 & 1 & 1 \\
\hline F4 & $1^{*}$ & 0 & 1 & 1 & $1^{*}$ & 1 & 1 & 1 & 1 & 0 \\
\hline F5 & $1^{*}$ & 0 & 1 & 1 & 1 & 1 & $1^{*}$ & 1 & 1 & 1 \\
\hline F6 & $1^{*}$ & 0 & $1^{*}$ & $1^{*}$ & 1 & 1 & 0 & $1^{*}$ & 1 & $1^{*}$ \\
\hline F7 & $1^{*}$ & 0 & $1^{*}$ & $1^{*}$ & 1 & 1 & 1 & $1^{*}$ & 1 & $1^{*}$ \\
\hline F8 & 0 & 0 & $1^{*}$ & $1^{*}$ & 1 & 1 & 0 & 0 & $1^{*}$ & $1^{*}$ \\
\hline F9 & 1 & 0 & 1 & 1 & 1 & 1 & $1^{*}$ & 1 & 1 & 0 \\
\hline F10 & $1^{*}$ & 0 & 1 & 1 & 1 & 1 & 1 & 1 & 1 & 1 \\
\hline
\end{tabular}

Table- V: Level Matrix

\begin{tabular}{|c|c|}
\hline Factors & Level \\
\hline F1 & III \\
\hline F2 & IV \\
\hline F3 & I \\
\hline F4 & I \\
\hline F5 & I \\
\hline F6 & I \\
\hline F7 & IV \\
\hline F8 & II \\
\hline F9 & I \\
\hline F10 & II \\
\hline
\end{tabular}

Table- VI: Partition of the reachability matrix

\begin{tabular}{|l|l|l|l|l|l|}
\hline Iterations & Factors & Reachability set & Antecedent set & Intersection & Level \\
\hline \multirow{5}{*}{ Iteration 1 } & F1 & $1,3,4,5,6,8,9,10$ & $1,2,3,4,5,6,7,9,10$ & $1,3,4,5,6,9,10$ & \\
\cline { 2 - 7 } & F2 & $1,2,3,4,5,6,8,9,10$ & 2 & 2 & \\
\cline { 2 - 7 } & F3 & $1,3,4,5,6,7,8,9,10$ & $1,2,3,4,5,6,7,8,9,10$ & $1,3,4,5,6,7,8,9,10$ & I \\
\cline { 2 - 7 } & F4 & $1,3,4,5,6,7,8,9$ & $1,2,3,4,5,6,7,8,9,10$ & $1,3,4,5,6,7,8,9$ & I \\
\cline { 2 - 7 } & F5 & $1,3,4,5,6,7,8,9,10$ & $1,2,3,4,5,6,7,8,9,10$ & $1,3,4,5,6,7,8,9,10$ & I \\
\cline { 2 - 7 } & F6 & $1,3,4,5,6,8,9,10$ & $1,2,3,4,5,6,7,8,9,10$ & $1,3,4,5,6,8,9,10$ & I \\
\cline { 2 - 7 } & F7 & $1,3,4,5,6,7,8,9,10$ & $3,4,5,7,9,10$ & $3,4,5,7,9,10$ & \\
\cline { 2 - 7 } & F8 & $3,4,5,6,8,9,10$ & $1,2,3,4,5,6,7,8,9,10$ & $3,4,5,6,8,9,10$ & \\
\cline { 2 - 7 } & F9 & $1,3,4,5,6,7,8,9,10$ & $1,2,3,4,5,6,7,8,9,10$ & $1,3,4,5,6,7,8,9,10$ & I \\
\cline { 2 - 6 } & F10 & $1,3,4,5,6,7,8,9,10$ & $1,2,3,5,6,7,8,9,10$ & $1,3,5,6,7,8,9,10$ & \\
\hline
\end{tabular}


Identification of Essential Elements in Maintaining Efficient Boiler System of a Coal Fired Thermal Power Plant

Table- VII: Interaction matrix

\begin{tabular}{|c|c|c|c|c|c|c|c|c|c|c|}
\hline Factors & F1 & $\mathrm{F} 2$ & F3 & $\mathrm{F} 4$ & F5 & F6 & F7 & F8 & F9 & F10 \\
\hline F1 & & & & & $\begin{array}{l}\text { Due to } \\
\text { sticky ash } \\
\text { removed. } \\
\text { Heat } \\
\text { transfer } \\
\text { improved }\end{array}$ & $\begin{array}{l}\text { Improved } \\
\text { rate of heat } \\
\text { transfer } \\
\text { help to } \\
\text { maintain } \\
\text { pressure } \\
\text { and } \\
\text { temperature }\end{array}$ & & & $\begin{array}{l}\text { Reduce flue } \\
\text { gas } \\
\text { temperature } \\
\text { due to } \\
\text { improved } \\
\text { teat transfer }\end{array}$ & \\
\hline F2 & & & & & $\begin{array}{l}\text { It helps to } \\
\text { operate up } \\
\text { to } \\
\text { designed } \\
\text { load }\end{array}$ & $\begin{array}{l}\text { Optimized } \\
\text { blow down } \\
\text { helps to } \\
\text { maintain } \\
\text { steam } \\
\text { parameters }\end{array}$ & & & $\begin{array}{l}\text { Scaling } \\
\text { avoided } \\
\text { heat } \\
\text { transfer } \\
\text { improved } \\
\text { so flue gas } \\
\text { temperature } \\
\text { reduced }\end{array}$ & \\
\hline F3 & & & & $\begin{array}{l}\text { best draft } \\
\text { control } \\
\text { reduce } \\
\text { excess } \\
\text { air }\end{array}$ & $\begin{array}{l}\text { best draft } \\
\text { control } \\
\text { helps to } \\
\text { maintain } \\
\text { optimum } \\
\text { load }\end{array}$ & $\begin{array}{l}\text { It helps } \\
\text { complete } \\
\text { combustion } \\
\text { and easy to } \\
\text { maintain } \\
\text { steam } \\
\text { parameters }\end{array}$ & & $\begin{array}{l}\text { it helps } \\
\text { even to } \\
\text { poor } \\
\text { quality fuel } \\
\text { to complete } \\
\text { combustion }\end{array}$ & $\begin{array}{l}\text { Both are } \\
\text { has high } \\
\text { relation and } \\
\text { heat } \\
\text { transfer }\end{array}$ & $\begin{array}{l}\text { Lower } \\
\text { ambient air } \\
\text { temperature } \\
\text { reduce } \\
\text { current } \\
\text { consumptio } \\
\mathrm{n}\end{array}$ \\
\hline F4 & & & $\begin{array}{l}\text { Excess air } \\
\text { easy the } \\
\text { process if } \\
\text { draft control }\end{array}$ & & & $\begin{array}{l}\text { Excess air } \\
\text { reduce } \\
\text { furnace } \\
\text { temperature } \\
\text { and affect } \\
\text { parameter }\end{array}$ & & $\begin{array}{l}\text { Poor } \\
\text { quality fuel } \\
\text { need more } \\
\% \text { of excess } \\
\text { air }\end{array}$ & $\begin{array}{l}\text { Excess air } \\
\text { reduce flue } \\
\text { gas } \\
\text { temperature }\end{array}$ & \\
\hline F5 & & & $\begin{array}{l}\text { Correct\% of } \\
\text { load easy to } \\
\text { control draft }\end{array}$ & $\begin{array}{l}\text { It helps } \\
\text { to reduce } \\
\text { excess } \\
\text { air }\end{array}$ & & $\begin{array}{l}\text { In optimum } \\
\text { loading } \\
\text { point the } \\
\text { parameters } \\
\text { will be } \\
\text { normal }\end{array}$ & & $\begin{array}{l}\text { Less } \\
\text { quantity of } \\
\text { good fuel } \\
\text { enough to } \\
\text { reach } \\
\text { required } \\
\text { load }\end{array}$ & $\begin{array}{l}\text { Correct } \% \\
\text { of this will } \\
\text { maintain } \\
\text { parameters } \\
\text { well }\end{array}$ & $\begin{array}{l}\text { Lower \% of } \\
\text { load helps } \\
\text { easy in hot } \\
\text { weather }\end{array}$ \\
\hline F6 & & & & & $\begin{array}{l}\text { It helps to } \\
\text { reach the } \\
\text { required } \\
\text { load }\end{array}$ & & & & $\begin{array}{l}\text { If correct } \\
\text { parameters } \\
\text { are } \\
\text { maintained } \\
\text { the flue gas } \\
\text { temperature } \\
\text { will reduce }\end{array}$ & \\
\hline F7 & & & & & $\begin{array}{l}\text { Poor } \\
\text { insulation } \\
\text { leads heat } \\
\text { loss it } \\
\text { affects } \\
\text { loading } \\
\end{array}$ & $\begin{array}{l}\text { It helps to } \\
\text { maintain } \\
\text { steam } \\
\text { parameters }\end{array}$ & & & $\begin{array}{l}\text { Poor } \\
\text { insulation } \\
\text { reduce flue } \\
\text { gas } \\
\text { temperature }\end{array}$ & \\
\hline F8 & & & & & $\begin{array}{l}\text { Less good } \\
\text { quality } \\
\text { fuel } \\
\text { enough to } \\
\text { reach full } \\
\text { load }\end{array}$ & $\begin{array}{l}\text { Parameter } \\
\text { easily } \\
\text { reached in } \\
\text { good } \\
\text { quality fuel }\end{array}$ & & & $\begin{array}{l}\text { Less } \\
\text { quantity if } \\
\text { good fuel } \\
\text { optimise } \\
\text { flue gas } \\
\text { temperature }\end{array}$ & \\
\hline F9 & $\begin{array}{l}\text { correct flue } \\
\text { gas } \\
\text { temperature } \\
\text { will reduce } \\
\text { soot } \\
\text { blowing } \\
\text { frequency }\end{array}$ & & $\begin{array}{l}\text { It helps to } \\
\text { reduce draft } \\
\text { control } \\
\text { frequency }\end{array}$ & $\begin{array}{l}\text { It } \\
\text { indicates } \\
\text { the over } \\
\text { doss of } \\
\text { excess } \\
\text { air }\end{array}$ & $\begin{array}{l}\text { It affects } \\
\text { percentage } \\
\text { of loading }\end{array}$ & $\begin{array}{l}\text { It indicate } \\
\text { the reason } \\
\text { for poor } \\
\text { steam } \\
\text { parameters }\end{array}$ & & $\begin{array}{l}\text { It helps in } \\
\text { complete } \\
\text { firing of } \\
\text { coal and } \\
\text { remove } \\
\text { moisture }\end{array}$ & & \\
\hline
\end{tabular}




\begin{tabular}{|c|c|c|c|c|c|c|c|}
\hline F10 & $\begin{array}{l}\text { Due to Less } \\
\text { ambient } \\
\text { temperature, } \\
\text { volume of } \\
\text { air to be } \\
\text { handled will } \\
\text { reduced for } \\
\text { the same } \\
\text { mass flow } \\
\text { rate }\end{array}$ & $\begin{array}{l}\text { Draft } \\
\text { control } \\
\text { will be } \\
\text { very easy } \\
\text { in good } \\
\text { ambient } \\
\text { conditio } \\
n\end{array}$ & $\begin{array}{l}\text { It help in } \\
\text { condenser } \\
\text { cooling } \\
\text { and } \\
\text { maintain } \\
\text { the unit } \\
\text { vacuum } \\
\text { good }\end{array}$ & $\begin{array}{l}\text { It helps in } \\
\text { improving } \\
\text { steam } \\
\text { parameters }\end{array}$ & $\begin{array}{l}\text { High } \\
\text { ambient } \\
\text { temperature } \\
\text { reduce rate } \\
\text { of heat } \\
\text { transfer } \\
\text { even in } \\
\text { poor } \\
\text { insulation } \\
\text { also }\end{array}$ & $\begin{array}{l}\text { High } \\
\text { ambient } \\
\text { temperature } \\
\text { helps in } \\
\text { removing } \\
\text { coal } \\
\text { moisture } \\
\text { and avoid } \\
\text { initial air } \\
\text { heating }\end{array}$ & $\begin{array}{l}\text { High } \\
\text { ambient } \\
\text { temperature } \\
\text { helps to } \\
\text { maintain } \\
\text { flue gas } \\
\text { temperature }\end{array}$ \\
\hline
\end{tabular}

\section{REFERENCES}

1. K. Mahkamov, P. Pili, R. Manca, A. Leroux, A. C. Mintsa, K. Lynn, and C. Costa Pereira, "Development of a small solar thermal power plant for heat and power supply to domestic and small business building," 2018.

2. S. K. Guttikunda and P. Jawahar, "Atmospheric emissions and pollution from the coal-fired thermal power plants in India," Atmospheric Environment, Vol. 92, 2014, 449-460.

3. J. Hao, L. Wang, M. Shen, L. Li and J. Hu, "Air quality impacts of power plant emissions in Beijing," Environmental Pollution, Vol. 147(2), 2007, 401-408

4. D. Das Adhikary, G. Kumar Bose, D. Bose and S. Mitra, "Multi criteria FMECA for coal-fired thermal power plants using COPRAS-G," International Journal of Quality \& Reliability Management, Vol. 31(5), 2014, 601-614.

5. M. C. Eti, S. O. T. Ogaji and S. D. Probert, "Integrating reliability, availability, maintainability and supportability with risk analysis for improved operation of the Afam thermal power-station," Applied Energy, Vol. 84(2), 2007, 202-221.

6. A. Gupta, M. Chandra Gupta and R. Agrawal, "Identification and ranking of critical success factors for BOT projects in India,' Management Research Review, Vol. 36(11), 2013, 1040-1060.

7. Z. Liu, S. Liang, Y. Geng, B. Xue, F. Xi, Y. Pan and T. Fujita, "Features, trajectories and driving forces for energy-related GHG emissions from Chinese mega cites: the case of Beijing, Tianjin, Shanghai and Chongqing," Energy, Vol. 37(1), 2012, 245-254.

8. M. E. Goerndt, F. X. Aguilar and K. Skog, "Drivers of biomass co-firing in US coal-fired power plants," biomass and bioenergy, Vol. 58, 2013, 158-167.

9. P. Regulagadda, I. Dincer and G. F. Naterer, "Exergy analysis of a thermal power plant with measured boiler and turbine losses," Applied Thermal Engineering, Vol. 30(8-9), 2010, 970-976.

10. S. Sushil, "Interpreting the interpretive structural model," Global Journal of Flexible Systems Management, Vol. 13(2), 2012, 87-106.

11. J. N. Warfield, "On arranging elements of a hierarchy in graphic form,' IEEE Transactions on Systems, Man, and Cybernetics, Vol. (2), 1973, 121-132.

12. B. Sankaranarayanan, K. Rahul, J. Pradeep, S. G. Ponnambalam, and S. Saravanasankar, "Evaluation of Influence of Principles Involved in Industry 4.0 Over Coal Industries Using TISM," In Industry 4.0 and Hyper-Customized Smart Manufacturing Supply Chains (pp. 244-262). IGI Global, 2019.

13. R. K. A. Bhalaji, S. Bathrinath and S. Saravanasankar, "Analysis of risk factors related to patients in healthcare industry using ISM method," In AIP Conference Proceedings, Vol. 2128, 1, 2019, 050003, AIP Publishing.

14. Y. Li, B. Sankaranarayanan, D. T. Kumar and A. Diabat, "Risks assessment in thermal power plants using ISM methodology," Annals of Operations Research, 1-25, 2019.

\section{AUTHORS PROFILE}

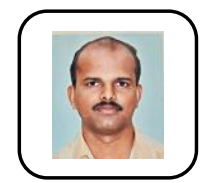

T. Sivageerthi obtained his B.E (MECH) in 2002 from the Government College of Engineering, Thirunelveli, Tamilnadu, India. He completed his M.Tech (Thermal Engineering) in 2005 at the JRN Vidyapeed (Deemed) university, udaipur, Rajasthan, India. Currently, he is working in Tuticorin Thermal power Station, (Tangedco) as Assistant Executive Engineer, Turbine maintenance 1 division and a External Research Scholar in the Department of Mechanical Engineering, Kalasalingam Academy of Research and Education,
.Krishnankoil, Tamilnadu, India. His research interests include Energy and exergy analysis of $210 \mathrm{MW}$ coal fired thermal power plant He is currently pursuing PHD in the area of estimation and sequestration of co 2 emission through energy analysis in coal-fired power plant.

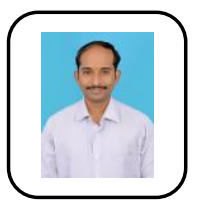

Dr.S.Bathrinath is an Associate Professor in the Department of Mechanical Engineering, Kalasalingam Academy of Research and Education, Krishnankoil, Tamilnadu, India. His current area of research includes multi-criteria decision making, scheduling \& optimization, soft computing and Artificial intelligence. He has published a number of papers in journal of national/international repute and presented a number of papers in various conferences/symposia in India and abroad. He is presently guiding a number of master/doctoral research scholars. Dr.S.Bathrinath is the corresponding author and can be contacted at: bathri@gmail.com

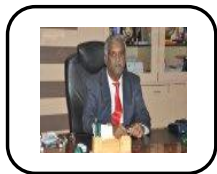

Dr.S.Saravanasankar is a Senior Professor in the Department of Mechanical Engineering, Kalasalingam Academy of Research and Education, Krishnankoil, Tamilnadu, India. He has more than 20 years of experience in teaching and research. His current area of research includes scheduling, optimization and multi-criteria decision making. He has published more than 40 research articles in journals of national and international repute. 